University of Nebraska - Lincoln

DigitalCommons@University of Nebraska - Lincoln

Faculty Publications: Department of Teaching, Department of Teaching, Learning and Teacher Learning and Teacher Education

Education

7-2011

\title{
Using the Communication in Science Inquiry Project professional development model to facilitate learning middle school genetics concepts
}

\author{
Dale R. Baker \\ Arizona State University, DALE.BAKER@asu.edu \\ Elizabeth B. Lewis \\ University of Nebraska-Lincoln, elewis3@unl.edu \\ Sibel Uysal \\ Arizona State University \\ Senay Purzer \\ Purdue University, spurzer@purdue.edu \\ Michael Lang \\ National Center for Teacher Education, Maricopa Community College District, \\ mike.lang@domail.maricopa.edu \\ See next page for additional authors \\ Follow this and additional works at: https://digitalcommons.unl.edu/teachlearnfacpub \\ Part of the Teacher Education and Professional Development Commons
}

Baker, Dale R.; Lewis, Elizabeth B.; Uysal, Sibel; Purzer, Senay; Lang, Michael; and Baker, Perry, "Using the Communication in Science Inquiry Project professional development model to facilitate learning middle school genetics concepts" (2011). Faculty Publications: Department of Teaching, Learning and Teacher Education. 124.

https://digitalcommons.unl.edu/teachlearnfacpub/124

This Article is brought to you for free and open access by the Department of Teaching, Learning and Teacher Education at DigitalCommons@University of Nebraska - Lincoln. It has been accepted for inclusion in Faculty Publications: Department of Teaching, Learning and Teacher Education by an authorized administrator of DigitalCommons@University of Nebraska - Lincoln. 


\section{Authors}

Dale R. Baker, Elizabeth B. Lewis, Sibel Uysal, Senay Purzer, Michael Lang, and Perry Baker 


\title{
Using the Communication in Science Inquiry Project professional development model to facilitate learning middle school genetics concepts
}

\author{
Dale R. Baker, ${ }^{1}$ Elizabeth B. Lewis, ${ }^{2}$ Sibel Uysal, ${ }^{3}$ Senay Purzer, ${ }^{4}$ \\ Michael Lang, ${ }^{5}$ and Perry Baker ${ }^{6}$
}

1. MaryLou Fulton Teachers College, Arizona State University, Arizona, USA

2. College of Education and Human Sciences, University of Nebraska-Lincoln, Lincoln, Nebraska, USA

3. King Life Science Building, Florida State University, Florida, USA

4. Engineering Education, Purdue University, West Lafayette, Indiana, USA

5. National Center for Teacher Education, Maricopa Community College District, Tempe, Arizona, USA

6. Southwestern College, Phoenix, Arizona, USA

Corresponding author - D. R. Baker, email dale.baker@asu.edu

\begin{abstract}
This study describes the effect of embedding content in the Communication in Inquiry Science Project professional development model for science and language arts teachers. The model uses four components of successful professional development (content focus, active learning, extended duration, participation by teams of teachers from the same school or grade level) and instructional strategies for inquiry, academic language development, written and oral discourse, and learning principles as components of science activities. Teachers were given a pre/ post-institute genetics assessment. There was a statistically significant increase in scores for the entire sample and a statistically significant difference between science and language arts pre and post scores, with science teachers scoring higher in both cases.
\end{abstract}

Keywords: professional development, biology, middle school teachers

\section{Introduction}

Wilson and Berne (1999), in their review of research, found that there is a consensus among scholars as to the characteristics of successful professional development. These include: long-term professional development; school-based and collaborative participation by teachers; active learning; and a subject matter focus. The Communication in Inquiry Science Project (CISIP) model of professional development includes these aspects of professional development and provides teachers with opportunities to develop the knowledge and skills to create and use lessons that address learning principles, support oral and written discourse, and facilitate academic language development of students in the context of scientific inquiry and specific science content. 


\section{Purpose}

The purpose of this study was twofold. The first purpose was to determine whether embedding genetics content in activities that contained the components of the CISIP model of professional development (Baker et al. 2007, Lewis et al. 2007, Ozdemir et al. 2007) would help middle school science teachers work towards becoming highly qualified as defined by the No Child Left Behind Act of 2001 (US Department of Education 2002). This content focus addressed the most influential component of successful professional development identified by Desimone (2009) in her recent review of the professional development literature.

The second purpose of the research was to determine whether embedding genetics content in professional development activities that integrated the components of the CISIP model would help middle school language arts teachers learn genetics concepts as they interacted in their school-based science and language arts teams. The rationale for including language arts teachers as part of the professional development was the belief that their increased understanding of science concepts would facilitate collaboration with science teachers and would improve cross-disciplinary understanding and planning. This school-based team approach also addressed a critical component of professional development - participation by teachers from the same school or grade level to facilitate the creation of learning communities and development teams (Diaz-Maggioli 2004).

Genetics was chosen as the content focus because it is one of the five sub-areas in biology on the Arizona Educator Proficiency Assessment. This assessment is used by the state to meet the standard of a highly qualified teacher. The content focus of the professional development was also selected to help teachers create a knowledge-centered classroom environment (Donovan and Bransford 2005).

The professional development took place during a summer institute where teachers engaged in hands-on activities over the course of three weeks. This aspect of the professional development addressed the need for long-term professional development to facilitate classroom change (Dori and Herscovitz 2005) as well as collaboration among teachers and student achievement (Sparks and Hirsch 1977, Daniels et al. 2001) and was followed by professional development Saturdays once a month throughout the academic year.

\section{Literature review}

\section{Effect of content knowledge on teaching}

Subject matter knowledge alone is insufficient preparation for teaching (Feiman-Nemser and Parker 1990, Banilower et al. 2007) but subject matter knowledge does affect teaching and learning in many ways. The National Commission on Teaching and America's Future highlights the importance of teacher subject matter knowledge, and, of course, how teachers teach, by identifying teacher subject matter knowledge as critical for student learning in all content areas (Darling-Hammond 1996).

Subject matter knowledge is also an important component in the development of pedagogical content knowledge (Abell 2007). There are positive correlations between training in science (subject matter knowledge) and teaching effectiveness, and the use of a variety of preferred teaching strategies in science (Druva and Anderson 1983, Abell 2007). For ex- 
ample, teachers with more science knowledge are more likely to teach science processes than teachers with less science knowledge (Dobey 1984). In addition, teachers with more science knowledge are also more likely to be more student-centered and less teacher-directed than teachers with less science content knowledge (Dobey and Schafer 1984).

Particularly important to this study is the work of Lee (1995) and Weiss et al. (2001). Lee (1995) found that middle school science teachers with limited science knowledge relied heavily on textbooks and individual seatwork, and generally avoided whole class discussions and inquiry activities. Weiss et al. (2001) found that $67 \%$ of middle school science teachers who responded to a national survey reported that they did not have a sufficient depth of science content knowledge.

The form that a teacher's knowledge takes is also important. To be effective, teachers' subject matter knowledge must be well organized and integrated. Teachers whose knowledge of biology lacks organization and integration cannot help students to link factual knowledge to larger conceptual frameworks and are unable to help students make connections to the natural world (Fisher and Moody 2000, Wandersee and Fisher 2000). Of particular note is that linking factual knowledge to conceptual frameworks and making connections to the natural world are two of the learning principles emphasized by the National Research Council (1999) in How People Learn and in the CISIP professional development model.

\section{Effects of subject matter knowledge-focused professional development}

Rigorous empirical research on the impact of professional development is limited and many studies are really descriptions of activities and strategies or reports of anecdotal data (Webster-Wright 2009). However, there is evidence that subject matter knowledgefocused professional development is important. Generic professional development has been found to have little impact on student learning in contrast to professional development with a strong focus on subject matter knowledge (Kennedy 1999, Cohen and Hill 2000). Furthermore, content-rich professional development is more likely to have an impact on teachers. Garet et al. (1999) found that teachers reported that content-focused professional development paired with active learning increased their subject matter knowledge and changed the way they taught. Jones et al. (2009) found that professional development was able to increase both teachers' mathematical and pedagogical content knowledge. Data from the National Science Foundation's Local Systemic Change through Teacher Enhancement Initiative (Banilower et al. 2007) also indicated that subject matter knowledge-focused professional development increased teachers' perceptions of their content preparedness. In addition, teachers who reported that they were more confident about their subject matter knowledge, as a result of their participation in Local Systemic Change professional development, tended to report more frequent use of inquiry approaches to teaching.

In contrast, traditional formats for professional development have little impact on the acquisition of subject matter knowledge. When the Cheche Konnen Project (Rosebery and Ogonowski 1996, Rosebery and Warren 1998) used a traditional model, they found that teachers had acquired no new knowledge about science. When they revised the professional development to create scientific communities where teachers and biologists engaged in discourse to develop shared meaning, increased the duration of the professional development and engaged teachers in inquiry and the exploration of their own questions, they increased teachers' understanding of content. Teachers' content knowledge was 
also enhanced using the City College Center workshop approach. In this two-week format of professional development, the emphasis was on forming hypotheses, designing experiments, asking questions, recording data, analyzing results and presenting findings (Loucks-Horsley et al. 1998).

Content-focused professional development can also have a positive effect on student science achievement. Kahle et al. (2000) engaged middle school teachers' professional development with a focus on inquiry and the content of physics, biology and mathematics using the Physics by Inquiry model developed by McDermott et al. (1996). Summer content institutes were six weeks long with follow-up sessions during the academic year. The follow-up sessions focused on equity issues related to teaching using inquiry, alternative assessment, standards and using technology. Urban African- American students of teachers who had participated in the professional development had higher science achievement scores than urban African-American students of teachers who had not participated in the professional development. Yager (2005) also documents the positive effect of content-focused professional development on student science achievement across grade levels and in varying contexts using a variety of assessment tools in his book Exemplary Science Best Practices in Professional Development.

\section{Pedagogical content knowledge}

Subject matter knowledge is an important domain of knowledge, along with pedagogical knowledge and pedagogical content knowledge (Shulman 1986). Despite the importance of subject matter knowledge, pedagogical knowledge and pedagogical content knowledge, the relationships among these forms of knowledge are complex and not well understood (Zeidler 2002). What we do know is that subject matter knowledge does not impact teachers' classroom practice without opportunities for reflection. Nor does a teacher's subject matter knowledge have an impact on students in the absence of pedagogical knowledge (Gess-Newsome and Lederman 1995, Baxter and Lederman 1999), because pedagogical knowledge provides teachers with the tools for ' ... formulating and representing the subject matter that make it comprehensible to others' (Shulman 1986, p. 9).

\section{Research questions}

This study was designed to determine whether embedding genetics content activities in the CISIP model of professional development had an effect on middle school science and language arts teachers' understanding of basic principles of inheritance. The research questions were as follows:

(1) Do genetics inquiry activities that use learning principles, promote academic language development and include opportunities to engage in oral and written discourse lead to significant increases in teacher understanding of genetics concepts?

(2) Is there a significant difference in the genetics test scores of middle school science and middle school language arts teachers?

(3) Do science and language arts teachers benefit equally from CISIP professional development that focuses on genetics concepts?

(4) Which genetics concepts were resistant to instruction from pre to post testing? 


\section{Structure and content of the summer institute}

\section{The CISIP model of professional development}

The CISIP model of professional development embeds subject matter content within inquiry activities that apply learning principles (National Research Council 2005). Inquiry activities have also been expanded to include opportunities to discuss and write about science, develop scientific vocabulary and craft scientific arguments.

\section{Learning principles of the CISIP model of professional development}

There are five learning principles in the CISIP model derived from the research on learning (National Research Council 2005) that were used to guide professional development activities. The five principles are: linking facts to conceptual frameworks; establishing performance expectations; fostering metacognitive monitoring; using formative assessments and providing feedback; and identifying prior understandings. These fundamental principles are applicable to any content area, although the specifics of how they are instantiated in different content areas will vary. The Appendix aligns the learning principles with the professional development activities.

We linked facts to conceptual frameworks by our choice of inquiry activities, discussions of the 'big ideas' and through writing scientific explanations with claims, evidence and reasoning where the reasoning had to address the larger conceptual framework that the data exemplified. We established performance expectations and provided feedback for formative assessment by giving teachers rubrics for the evaluation of their work and using peer and facilitator feedback on public presentations of their work. We also established norms for how to organize and use notebooks and what should be found in each teacher's notebook. Prior knowledge was identified before inquiry activities through discussions and self-assessments. Metacognitive monitoring was fostered through writing reflections in science notebooks about what had been learned and by providing teachers with opportunities to design and carry out experiments of their own choosing.

\section{Instructional strategies}

Inquiry was chosen as an instructional strategy because it is one of the unifying concepts and processes found across all grade levels in the National Science Education Standards (National Research Council 1996). In addition, it is an essential component of the Professional Development Standard A, which states that: 'Professional development for teachers of science requires learning essential content through the perspectives and methods of inquiry' (National Research Council 1996, p. 4). The CISIP definition of inquiry includes: providing opportunities to ask questions about the natural world; designing and planning explorations of the natural world; using data to explain the results of scientific exploration; engaging in in-depth discussions about data and explanations; and generating oral and written scientific arguments from data that link claims, evidence and reasoning.

We chose genre writing including patterns of argumentation (Halliday and Martin 1993) as an instructional strategy because, according to Moore (1993), students' science achievement improved when writing was coupled with explicit writing instruction and was embedded in science instruction. Additional writing strategies were taken from the 
research in writing-to-learn (Bereiter and Scardamalia 1987), especially in science (Klein 1999, Yore et al. 1999).

Academic language development strategies drew from the language principles of Carrasquillo and Rodriquez (1996) and the 'Cognitive Academic Language Approach' (Chamot and O'Malley 1987). These strategies build students' subject matter knowledge background, support student to student interactions and include frequent assessment (Echevarria et al. 2003). Additional discourse strategies to promote student to student talk were derived from the learning principles that address the norms for discussions in How Students Learn (National Research Council 2005). These strategies stress the role of oral language in the co-construction of knowledge (National Research Council 2005).

\section{School-based teams}

The CISIP project recruited school-based teams of middle school teachers to participate in the professional development. This model is supported by the research of Garet et al. (1999) who found that changes in knowledge, skills and teaching practices were most likely to occur if professional development took place over a long time span and encouraged participation by more than one teacher in a school or grade level.

\section{Summer institute}

The CISIP summer institute was held in the summer of 2007. It was designed to: improve teachers' subject matter knowledge of genetics; be an integral part of the school-wide or district-wide improvement plan to increase student achievement; provide knowledge and skills to address state and national science content and curriculum standards; have strong classroom applications; employ research-based instructional strategies; and employ the expertise of veteran teachers who had previously been participants in prior CISIP institutes.

The institute was held for three weeks Monday through Thursday, from 8:00 in the morning until 1:30 in the afternoon with a half hour for a lunch break. There were a total of 60 contact hours. Of those hours, 13 hours were spent engaged in four genetics laboratory inquiry activities. Institute activities were presented by a team consisting of university, community college and school district faculty.

The first three days of the institute were spent in exploring the CISIP model through various activities such as: reading 'Fish is Fish' (Lionni 1974) aloud to demonstrate how preconceptions affect students' understanding, watching video excerpts from Race for the Double Helix (1987) to look for examples of the various modes of scientific collaboration and communication, identifying specific aspects of the nature of scientific communication and setting up science notebooks.

\section{CISIP professional development genetics activities}

The genetics activities were designed to address some of the content on the Arizona Educator Proficiency Assessments (AEPA) Subject Knowledge Test for Middle Grades Science (AEPA n.d.). Given the criteria to address the national and state standards and AEPA em- 
phasis areas, as well as our time constraints, we selected four key genetics concepts related to the inheritance of biological traits to focus on during the professional development. These concepts were: how characteristics, including human traits, are passed from generation to generation; structure and functions of genes and chromosomes; the role of DNA and RNA in the transmission of genetic information; and Mendel's laws.

\section{Human characteristics}

On the fourth day of the institute, teachers engaged in the first genetics inquiry activity that examined human characteristics. This inquiry activity lasted three hours. Working in groups, the teachers took a handedness test by counting the number of zeros that could be marked in a 30-second time period with the right and then the left hand, counted the ridges on one of their 10 fingers from a print, and determined which eye was the master eye by looking through a hole at a distant object. Each group's data were reported and recorded in their science notebooks and a graph for the group's totals was constructed. Teachers were asked to answer a series of questions about the patterns in the data and to hypothesize which characteristics were controlled by one gene and which characteristic was controlled by multiple genes. The instructor then led a discussion of the hypotheses and supporting data. The human characteristics laboratory was followed by two more days of activities that exemplified the CISIP model (e.g. academic language development activities, deconstructing a scientific argument, mystery boxes).

\section{Gummy bears}

On the seventh and eighth days, teachers were engaged in two biology laboratories. The Gummy Bear laboratory activity (Baker and Thomas 1998) focused on inheritance of traits through generations (phenotype, genotype, dominant, recessive, lethal allele, Punnett Square, ratios). Each group was given a bag of candy gummy bears in several colors. The bears were sorted by alternative forms of a characteristic and the number of bears with each alternative form was counted. This constituted the data-set from which the teachers hypothesized ratios of alternative forms and probable genotypes and phenotypes of the original parental cross. Their hypotheses were tested by constructing Punnett squares and the ratio from the data was compared with the ratio predicted by the Punnett square. Teachers also used the evidence to propose possible modes of inheritance for the bear phenotypes in their bags. Class data were collated and a discussion of the general mechanism of inheritance suggested by the data concluded the activity. The Gummy Bear laboratory was supported by a vocabulary building activity and a symbol comprehension activity (e.g. Tt).

\section{DNA wheat extraction}

The wheat DNA extraction laboratory focused on the quantity and characteristics of the DNA extracted from the wheat as a function of using water of differing temperatures, as well as different brands of soaps, meat tenderizers and ethanol. The teachers recorded and drew their observations, then wrapped the DNA on a stick and again recorded and drew what they saw. The teachers then had the opportunity to develop their own questions and design their own experiment to look at variables that might affect the extraction process. Before the laboratory the teachers engaged in a metacognitive activity to access their prior knowledge about DNA, what they wanted to learn and how they wanted 
to learn. After the DNA extraction laboratory, the teachers wrote a scientific investigation report as homework, using the data they had collected. The report emphasized claims and evidence as key components of a scientific argument, as modeled in the institute. They then returned to their metacognitive writing and added what they learned. Days 9-11 were dedicated to working in school-based teams to develop lesson plans for the upcoming school year.

\section{Biobank}

On the final day of the institute, teachers worked on a biobank activity using one or more of nine Internet sites (for example, UK Biobank n.d.). Teachers searched the sites for definitions of key vocabulary concepts (e.g. population, genetic predisposition) and answered a set of 10 questions designed to help them think about controversial issues related to the storage of genetic information such as privacy, genetic illnesses, mandatory genetic testing and genetic discrimination, as well as ownership of genetic information and patenting of the genome. Teachers were also given two articles to discuss about buying the rights to the entire gene pool of the Tongan people (Williams 2000) and the misuse of blood samples from the Havasupi people (Jones 2004). These activities were followed by a wholegroup discussion about the ways biobank activities could be used with students to support their understanding of genetics concepts. The teachers were also given a list of eight activities to use with their students, such as writing a persuasive argument for or against biobanks or reviewing biobank sites.

Each genetics activity was followed by transfer questions that were discussed in the teacher groups and each activity used several components of the CISIP model to demonstrate how the components could be integrated into inquiry laboratories for students. Vocabulary and symbols were developed using strategies such as word walls, academic language strategies to support understanding of science content were modeled, arguments with claims and evidence were crafted and written into science notebooks, and the metacognitive process taking place during the activities was examined. Teachers were also provided with lesson plans so that they could replicate the activities in their own classrooms. Learning was reinforced through extensive writing in science notebooks, small group discussions and public presentations of findings from the laboratory activities in the form of claims and evidence.

The last four days of the institute were spent in knowledge transformation activities. The teams of science and language arts teachers worked together to create lessons that they would use in their individual classrooms in the coming year. This collaborative activity required the application of both pedagogical knowledge and subject matter knowledge acquired in the institute to lessons that would be appropriate for middle school students.

\section{Research study procedure}

\section{Participants}

Teachers participating in the institute ( $n=23,13$ science, 10 language arts) were recruited from high-needs districts who were partners in an Improving Teacher Quality grant funded by the Arizona Board of Regents. Selection within schools was based on the crite- 
rion that at least one science and one language arts teacher would work as a team. Eighteen $(75 \%)$ of the participants were female and six $(25 \%)$ were male. Five $(20.8 \%)$ of the participants were previous participants who had been involved in CISIP professional development for at least one year before attending the summer institute. The mean length of time teaching was 9.2 years $(S D=6.17)$. The mean number of courses in science content was 7.91, the mean number of methods of teaching science courses was 1.22, the mean number of English courses was 8.9 and the mean number of English methods courses was 3.0. Twenty-one $(87.5 \%)$ teachers were teaching in-field.

\section{Subject matter knowledge assessment in genetics}

A 35-item multiple-choice genetics assessment was created by one of the authors who was also responsible for the development of the genetics lessons and who provided the content instruction. The multiple choice format was chosen to match the format of the AEPA. This assessment must be passed in order to be classified as highly qualified. The genetics test assessed the factual and conceptual knowledge presented in the genetics laboratory activities. Face validity was established by Arizona State University faculty and graduate students who examined the test items for alignment with the content of the genetics activities and revisions were made as needed by adding or removing items to reflect the content of the activities. The assessment has a KR 20 reliability of 0.85 . The pre test was administered prior to the genetics activities on day two of the institute to ensure that all teachers were in attendance and the post test was administered on the last day of the institute. The pre tests and post tests used the same assessment. Both the science and language arts teachers took the assessment. Data were analyzed using $t$-tests and examined for item difficulty. An example of an assessment item is as follows, with the correct answer indicated by the asterisk:

In humans, widow's peak is considered a dominant trait, and a straight hairline is considered a recessive trait. The dominant allele exhibits complete dominance. If a couple both have widow's peak, what is the probability that they will have a child with a straight hairline?
(A) $75 \%$
(B) cannot be determined by looking at the parents*
(C) $2 / 3$
(D) $25 \%$
(E) $50 \%$

\section{Results}

\section{Comparison of pre tests and post tests}

An analysis of the data indicated that there was a statistically significant improvement in test scores for the entire sample of science and language arts teachers from pre test to post test $(t=5.88, p<0.000)$. Pre-test scores for the group had a mean of 17.39 and a standard deviation of 6.17. Post-test scores for the group had a mean of 22.85 and a standard deviation of 6.12. Thus, we can affirm the first research question: does embedding genetics activities within the CISIP model during a summer professional development institute lead to increased understanding of genetics concepts? 


\section{Comparison of science and language arts teachers}

The differences in the science and language arts teachers' pre tests and post tests were also statistically significant (pre-test $F=36.63, p<0.000$; post-test $F=16.91, p<0.001$ ), with science teachers scoring higher in both cases. Thus, we also affirm the second research question: was there a difference in test scores for middle school science and middle school language arts teachers? However, there was no significant interaction term, and the increases for science (4.9 points) and language arts teachers (5.2) were statistically the same. Consequently, the answer to research question three-do science and language arts teachers benefit equally from CISIP professional development that focuses on genetics concepts? - is also yes.

\section{Analysis of item difficulty}

With respect to the fourth research question - which genetics concepts were resistant to instruction from pre to post testing? - the data are less straightforward. Less than onehalf of the teachers were able to correctly answer 18 of the questions on the pre test. On the post test, only eight of these pre-test items were answered incorrectly. Teachers did develop an understanding of material dealing with genotype and phenotype, dominant and recessive genes, alleles and genetic material.

The most frequently incorrectly answered question on both the pre assessment and the post assessment dealt with autosomal dominant traits. We attribute this result to both the difficulty of the concept and professional development activities that did not explore the concept sufficiently. Two other questions that were answered incorrectly on both the pre and post assessment required an understanding of probability, which was also an under-developed concept. The most frequently incorrectly answered question required an understanding and application of all the genetics concepts presented in the professional development. It asked teachers to identify factors that would support the idea that the length of life has an inherited component. The question is as follows, with the correct answer indicated by an asterisk:

Which of the following would support the idea that length of life has an inherited component?

(A) an adopted child whose biological parent died before age 50 is more likely to die young than a similar member of the general population

(B) a child whose adoptive parents died before age 50 was no more likely to die young than a similar member of the general population

(C) a child whose monozygotic twin died before age 50 is more likely to die before 50 than a similar member of the general population

(D) all of these support the hypothesis that length of life has an inherited component*

(E) none of these support the hypothesis that length of life has an inherited component

\section{Discussion}

This professional development was successful because it contained critical components found in the professional development literature, including opportunities for active learning and intellectual engagement, opportunities for sustained learning in a collaborative 
format and a primary focus on content knowledge and pedagogy (Fickel 2002). These are design principles that transcend content or nations and are broad enough to be adapted worldwide to the particular local needs of teachers and school community contexts.

Our professional development design led to improved subject matter knowledge of biology teachers and language arts teachers to the same degree in terms of point gains from pre to post assessment. We attribute this finding to the strong content focus of the professional development. We also attribute gains in knowledge to the active learning component of the professional development using an inquiry approach. Teachers constructed their own knowledge as they devised experiments to extract wheat DNA, tried to figure out patterns of inheritance with the gummy bears and used Internet resources to explore and discuss the implications of storing genetic information in biobanks.

The active learning and content focus components can be adapted to many areas critical to enhancing both teacher and student learning. In addition to the obvious areas of exploring mathematical problems using manipulation or using modeling to explore physics concepts, active learning with a content focus can be applied to learning such things as new ways to assess students' knowledge of content. For example, teachers might discuss student work to determine what is actually being assessed and develop, use and revise rubrics to determine what kinds of understandings the student work demonstrates.

The school-based team structure provided two-way collegial support. Science teachers helped language arts teachers as they explored new content, and language arts teachers helped science teachers to engage in and understand the role of academic language development, discussion and writing to enhance learning in science. Other collaborations might include the mathematics teacher and the chemistry teacher, where the focus of the professional development addresses the mathematical overlap of both content areas and the pedagogies each teacher could use to facilitate transfer across content areas. Less traditional teams of technology and music teachers might collaborate to explore the technological changes that led to the evolution of musical instruments such as the piano, using historical documents. The physics teacher might become the third collaborator to help her colleagues understand how and why instruments make the sounds they do by exploring frequencies, waves and oscillations. All might use their knowledge of physics principles, such as the relationship of the length of a string on a guitar to the sound it produces, to engage in building their music skills and playing their own instruments.

The language components of extensive discussion, keeping a science notebook, developing academic language through vocabulary building and writing using scientific explanations provided the teachers with opportunities to clarify their understandings, link new knowledge with existing knowledge and deeply process information, which supports learning science (Lemke 1990, Duschl et al. 2007). These language components are not unique to science but can be applied to any content area. All active learning experiences are enhanced by discussing what has been learned using the vocabulary of the discipline; notebooks are learning tools for recording, reflecting and developing metacognitive understanding; and writing explanations using the genre of a specific discipline promotes literacy in that discipline.

The science instruction was embedded in extensive professional development that exceeded the 20 hours of contact usually recommended, and teachers knew that there would be follow-up professional development sessions during the academic year that would build upon the work started in the summer institute. Many other formats are also possible as long as they engage teachers in sustained professional development. Rather than 
starting with intensive professional development during a summer followed by monthly meetings during the academic year, the schedule could be reversed. Another structure might engage teachers in professional development for a two-day to three-day period, with a break of a month or two in which teachers try out what they have learned and then another round of two or three days of professional development, repeating this cycle several times. The school year schedule would influence the structure. The key point is that the professional development is both extensive and sustained over a long period of time rather than short and compressed.

This work contributes to the body of knowledge in teacher professional development in that it demonstrates how content knowledge can be enhanced by embedding inquiry laboratory activities in a professional development framework that contributes to learning. It may seem obvious to some that teachers would gain subject matter knowledge after attending a summer institute with a subject matter knowledge focus. However, there is sufficient evidence that not all professional development leads to learning (Wilson and Berne 1999, Speck and Knipe 2001) because the time is unstructured and there is a lack of focus. Furthermore, an examination of the effectiveness of professional development in enhancing teacher subject matter knowledge is rare. Most studies document factors such as changes in teacher attitude, satisfaction with the professional development experience or intentions to implement innovations in classrooms (Frechtling et al. 1995).

There are many contexts in which teacher learning can take place (Borko 2004). We believe that a professional development context that contains the critical components of professional development and also models effective instructional strategies and learning principles is a context that can maximize teacher learning across content areas. Although there is no doubt that teacher development and learning play a critical role in student achievement (Desimone et al. 2005), it is important to note that teacher learning must include subject matter knowledge, pedagogical knowledge and pedagogical content knowledge. This research has examined the first of these three factors. Future research will focus on the impact of teacher subject matter knowledge and fidelity of the implementation of the CISIP professional development model in classrooms on student achievement in science and students' ability to engage in discussion and writing about science.

To measure fidelity of implementation, we will be making classroom observations of teachers using the CISIP Classroom Observation Instrument. The CISIP Classroom Observation Instrument was developed to measure fidelity to the CISIP model (Ozdemir et al. 2007). In addition, we will collect student assessment data and samples of student work. After the data have been collected we will attempt to determine the effects of teacher content knowledge on student achievement and teacher fidelity to the CISIP model on student achievement as individual and combined factors.

Acknowledgments - The professional development activities for teachers and the research were funded by the National Science Foundation (grant number 0353469) and an Improving Teacher Quality state grant awarded by the Arizona Board of Regents. 


\section{References}

Abell, S. K., 2007. Research on science teacher knowledge. In: S. K. Abell and N. G. Lederman, eds. Handbook on research in science education. Mahwah, NJ: Lawrence Erlbaum Associates, 1105-1150.

Arizona Educator Proficiency Assessments, n.d. Subject knowledge test for middle grades science; online: http://www.aepa.nesinc.com/PDFs/AZ_field39_Study Guide.pdf [Accessed March 3, 2007].

Baker, D. R., Lang, M., and Ozdemir, G., 2007. The communication in science inquiry project: Lessons learned from professional development with secondary teachers. Paper presented at the annual meeting of the National Association for Research in Science Teaching, 15-18 April, New Orleans, LA.

Baker, W. and Thomas, C., 1998. Gummy bear genetics. The science teacher, November, 25-27.

Banilower, E., Heck, D., and Weiss, I., 2007. Can professional development make the vision of standards a reality? The impact of the National Science Foundation's local systemic change through teacher enhancement initiative. Journal of research in science teaching, 44 (3), 375-395.

Baxter, J. and Lederman, N., 1999. Assessment and measurement of pedagogical content knowledge. In: J. Gess-Newsome and N. Lederman, eds. Examining pedagogical content knowledge. Boston, MA: Kluwer Academic, 147-162.

Bereiter, C. and Scardamalia, M., 1987. The psychology of written composition. Hillsdale, NJ: Erlbaum.

Borko, H., 2004. Professional development and teacher learning: Mapping the terrain. Educational researcher, 33 (8), 3-15.

Carrasquillo, A. and Rodriquez, V., 1996. Language minority students in the mainstream classroom. Philadelphia, PA: Multilingual Matters.

Chamot, A. and O'Malley, J., 1987. The cognitive academic language learning approach: A bridge to the mainstream. TESOL Quarterly, 21 (2), 227-249.

Cohen, D. and Hill, H., 2000. Instructional policy and classroom performance: The mathematics reform in California. Teachers college record, 102 (2), 294-343.

Daniels, D., Bizar, M., and Zemelman, S., 2001. Rethinking high school best practices in teaching, learning, and leadership. Portsmouth, NH: Heinemann.

Darling-Hammond, L., 1996. What matters most: teaching for America's future. Washington, DC: National Commission on Teaching and America's Future.

Desimone, L., 2009. Improving impact studies of teachers' professional development: Toward better conceptualizations and measures. Educational researcher, 38 (3), 181-199.

Desimone, L., et al., 2005. Beyond accountability and average math scores: Relating multiple state education policy attributes to changes in student achievement in procedural knowledge, conceptual understanding and problem solving in mathematics. Educational measurement: issues and practice, 24 (4), 5-18.

Diaz-Maggioli, G., 2004. Teacher-centered professional development. Alexandria, VA: Association for Supervision and Curriculum Development.

Dobey, D.C. and Shafer, L. E., 1984. The effects of knowledge on elementary science inquiry teaching. Science education, 68 (1), 39-51.

Donovan, S. and Bransford, J., 2005. How students learn: Science in the classroom. Washington, DC: National Research Council.

Dori, Y. and Herscovitz, O., 2005. Case-based long-term professional development of science teachers. International journal of science education, 27 (12), 1413-1466.

Druva, C.A. and Anderson, R.D., 1983. Science teacher characteristics by teacher behavior and by student outcome: a meta-analysis of research. Journal of research in science teaching, 20 (5), 467-479.

Duschl, R., Schweingruber, H., and Shouse, A., 2007. Taking science to school: Learning and teaching science in grades K-8. Washington, DC: National Academies Press. 
Echevarria, J., Vogt, M., and Short, D., 2003. Making content comprehensible for English language learners: The SIOP model. Boston, MA: Allyn and Bacon.

Feiman-Nemser, S. and Parker, M. B., 1990. Making subject matter part of the conversation in learning to teach. Journal of teacher education, 41 (3), 32-43.

Fickel, L., 2002. Quality professional development: suggestions about process and content. The educational forum, 67 (1), 47-54.

Fisher, K. M. and Moody, D. E., 2000. Student misconceptions in biology. In: K. M. Fisher, J. H. Wandersee, and D. E. Moody, eds. Mapping biology knowledge. Boston, MA: Kluwer Academic, 55-76.

Frechtling, J., et al., 1995. Teacher enhancement programs: A perspective on the last four decades. Monograph. Arlington, VA: National Science Foundation Directorate for Education and Human Resources.

Garet, M., et al., 1999. Designing effective professional development: Lessons from the Eisenhower program. Washington, DC: US Department of Education.

Gess-Newsome, J. and Lederman, N., 1995. Biology teachers' perceptions of subject matter structure and its relationship to classroom practice. Journal of research in science teaching, 32 (3), 301-325.

Halliday, M. and Martin, J., 1993. Writing science. Pittsburgh, PA: University of Pittsburgh Press.

Jones, E., 2004. Havasupai blood samples misused. Indian Country Today, 9 March.

Jones, E., et al., 2009. Impacting teacher mathematical knowledge and attitudes with grade-appropriate methods. Professional development in education, 35 (2), 279-283.

Kahle, J., Meece, J., and Scantlebury, K., 2000. Urban African-American middle school science students: Does standards-based teaching make a difference? Journal of research in science teaching, 37 (9), 1010-1041.

Kennedy, M., 1999. Form and substance in mathematics and science professional development. NISE brief, vol. 3, no. 2. Madison, WI: University of Wisconsin-Madison, National Institute for Science Education.

Klein, P., 1999. Reopening inquiry into cognitive processes in writing to learn. Educational psychology review, 11 (3), 203-270.

Lee, O., 1995. Subject matter knowledge, classroom management, and instructional practices of middle school teachers. Journal of research in science teaching, 32 (4), 423-440.

Lemke, J., 1990. Talking science: language, learning and values. Norwood, NJ: Ablex.

Lewis, E. B., et al., 2007. Perceptions of secondary and post-secondary interdisciplinary faculty on CISIP professional development: A teacher learning community designing scientific classroom discourse communities. Paper presented at the annual meeting of the National Association for Research in Science Teaching, 15-18 April, New Orleans, LA.

Lionni, L., 1974. Fish is fish. New York: Dragonfly Books.

Loucks-Horsley, S., et al., 1998. Designing professional development for teachers of science and mathematics. Thousand Oaks, CA: Corwin Press.

McDermott, L., Shaffer, P., and Rosenquist, M., 1996. Physics by inquiry: An introduction to physics and the physical sciences. Vols. 1-2. New York: John Wiley.

Moore, R., 1993. Does writing about science improve learning about science? Journal of college science teaching, 22 (4), 212-217.

National Research Council, 1996. National science education standards. Washington, DC: National Academy Press.

National Research Council, 1999. How people learn. Washington, DC: The National Academy Press.

National Research Council, 2005. How students learn: History, mathematics and science in the classroom, a targeted report for teachers. Division of Behavioral and Social Sciences and Education. Washington, DC: The National Academy Press. 
Ozdemir, G., Lewis, E., and Baker, D., 2007. Development and validity of the CISIP (Communication in Science Inquiry Project) classroom observation instrument. Paper presented at the annual meeting of the National Association of Research in Science Teaching, 15-18 April, New Orleans, LA.

Race for the double helix, 1987. TV Film. Directed by Mick Jackson. USA/UK: A\&E Television/ BBC.

Rosebery, A. and Ogonowski, M., 1996. Valerie: Exploring the relationship between doing science and teaching science. Portsmouth, NH: Heinemann.

Rosebery, A. and Warren, B., 1998. Boats, balloons, and classroom video: Science teaching as inquiry. Portsmouth, NH: Heinemann.

Shulman, L., 1986. Those who understand: Knowledge growth in teaching. Educational researcher, 15 (2), 4-14.

Sparks, D. and Hirsch, S., 1997. A new vision for staff development. Alexandria, VA: Association for Supervision and Curriculum Development.

Speck, M. and Knipe, C., 2001. Why can't we get it right: Professional development in our schools. Thousand Oaks, CA: Corwin Press.

UK Biobank, n.d. Online: http://ukbiobank.ac.uk [Accessed April 14, 2007].

US Department of Education, Office of Elementary and Secondary Education, 2002. No Child Left Behind: a desktop reference. Washington, DC: Author.

Wandersee, J. H. and Fisher, K. M., 2000. Knowing biology. In: K. M. Fisher, J. H. Wandersee, and D. E. Moody, eds. Mapping biology knowledge. Boston, MA: Kluwer Academic, 39-54.

Webster-Wright, A., 2009. Reframing professional development through understanding authentic professional learning. Review of educational research, 79 (2), 702-739.

Weiss, I., et al., 2001. Report on the national survey of science and mathematics education. Chapel Hill, NC: Horizon Research.

Williams, V., 2000. Biotech firm buys Tongan peoples' entire gene pool. The Advertiser, 22 November, p. 2.

Wilson, S. and Berne, J., 1999. Teacher learning and the acquisition of professional knowledge: An examination of research on contemporary professional development. Review of research in education, 24 (1), 173-209.

Yager, R., 2005. Exemplary science best practices in professional development. Arlington, VA: National Science Teachers Association Press.

Yore, L., Hand, B., and Prain, V., 1999. Writing-to-learn science: Breakthroughs, barriers, and promises. Paper presented at the Association for the Education of Teachers of Science, 14-17 January, Austin, TX.

Zeidler, D., 2002. Dancing with maggots and saints: Visions for subject matter knowledge, pedagogical knowledge, and pedagogical content knowledge in science teacher education. Journal of science teacher education, 13 (1), 27-42. 
Appendix. CISIP learning principles and aligned activities

\begin{tabular}{lc}
\hline Learning Principles & Sample Professional Development Activities \\
\hline $\begin{array}{c}\text { Linking facts to conceptual } \\
\text { frameworks }\end{array}$ & $\begin{array}{c}\text { Inquiry lessons emphasizing linking facts and experiences to } \\
\text { promote patterned reasoning, assimilating new information } \\
\text { into existing frameworks of past lessons and real-world } \\
\text { experiences, and placing factual knowledge in a conceptual } \\
\text { framework using scientific explanations }\end{array}$ \\
$\begin{array}{c}\text { Establishing performance } \\
\text { expectations }\end{array}$ & $\begin{array}{c}\text { Using and creating rubrics to inform students of performance } \\
\text { expectations, techniques for providing students with } \\
\text { exemplars of quality work, and easy to follow guidelines }\end{array}$ \\
$\begin{array}{c}\text { Fostering students' } \\
\text { metacognitive monitoring }\end{array}$ & $\begin{array}{c}\text { Self-assessment activities to determine the effectiveness of } \\
\text { personal learning approaches and understanding of personal } \\
\text { learning approaches, opportunities to set the intensity or the } \\
\text { speed of work }\end{array}$ \\
$\begin{array}{c}\text { Using formative assessments } \\
\text { and providing feedback }\end{array}$ & $\begin{array}{c}\text { Immediate oral and/or written feedback following activities } \\
\text { Identifying prior } \\
\text { understandings }\end{array}$ \\
& $\begin{array}{c}\text { Modeling how to access prior knowledge, compare prior } \\
\text { knowledge with normative ideas in science, and how to } \\
\text { engage in discussions and reflect upon initial ideas and } \\
\text { conceptions }\end{array}$ \\
\hline
\end{tabular}

